Research Journal of Animal Sciences 4 (5): 117-120, 2010

ISSN: $1993-5269$

(C) Medwell Journals, 2010

\title{
Nutritive Value of Kyasuwa Hay (Pennisetum pedicellatum) Ensiled with Poultry Litter at Varying Proportions
}

\author{
${ }^{1} \mathrm{M}$. Baba, ${ }^{1} \mathrm{~T}$. Uba and ${ }^{2} \mathrm{~A} . \mathrm{R}$. Halim \\ ${ }^{1}$ Department of Animal Science, Bayero University, Kano, Nigeria \\ ${ }^{2}$ Department of Crop Science, University Putra, Malaysia
}

\begin{abstract}
Pennisetum pedicellatum (kyasuwa) hay was ensiled with poultry litter in varying proportions; $80: 20$, 70:30, 60:40, 50:50 and 100:0 (control), respectively in polythene bags under room temperature for 21 days. The resultant silage was analyzed for $\mathrm{pH}$, aroma, Crude Protein $(\mathrm{CP})$, Crude Fiber $(\mathrm{CF})$, Ether Extract (EE), ash and Nitrogen Free Extract $(\mathrm{NFE})$. The result of the study indicated significant differences $(p<0.05)$ among the treatments in terms of $\mathrm{pH}$, aroma, $\mathrm{CP}, \mathrm{CF}, \mathrm{NFE}$ and ash but non significant differences in Dry Matter (DM) and EE. Ensiling with poultry litter increased $\mathrm{pH}, \mathrm{CP}, \mathrm{DM}$ and $\mathrm{NFE}$ while $\mathrm{CF}$, ash and $\mathrm{EE}$ declined. $\mathrm{CP}$ and $\mathrm{DM}$ increased with increased proportion of poultry litter while CF and ash decreased. No definite trend was observed for $\mathrm{pH}, \mathrm{EE}$ and NFE. Treatment 50:50 had the highest $\mathrm{DM}(93.18 \%)$ and $\mathrm{CP}(4.65 \%)$ while control recorded the least (CP 1.64\%, DM 92.29\%). Crude Fiber (CF) was lowest in treatment 50:50. It was concluded that ensiling kyasuwa hay with up to $50 \%$ poultry litter improved the feeding value of the silage significantly.
\end{abstract}

Key words: Poultry litter, silage, proximate composition, livestock, industry, natural grass growth

\section{INTRODUCTION}

The problem of feed inadequacy during a particular period of the year has been a major concern among livestock industry players in northern region of Nigeria. The region which harbours the bulk of livestock population in Nigeria has two distinct seasons, the rainy season ( 4 months) and dry season ( 8 months). During the rainy season there is usually abundance of feed in the form of natural grass growth which declines way into the dry season. Livestock owners and their herd are therefore, forced to migrate southwards in search of feed and water for the animals with consequent loss in body weight, loss in energy consumed due to long distance trekking and also reduction in both productive and reproductive capacities (FAO, 1983). Tropical grasses have been reported to contain as low as $8 \%$ crude protein (Humphreys, 1991).

One of the ways of mitigating these problems is through improvement in the feeding value of grass hays usually found in abundance during the dry season. This could be done by ensiling with animal waste such as poultry litter. Animal waste is one of the most important but underutilized resources with a huge quantity produced by livestock yearly (Fontenot and Jurusbescu, 1980). Disposal of animal waste on to land has been the traditional practice of the animal industry, this practice has remained attractive for a long time due to its benefit of maintaining soil fertility, securing a convenient channel of waste disposal and harvesting nutrient in food and feed crops (Bhattacharya and Taylor, 1975). In recent times livestock owners have had to grapple with problem of waste disposal in densely populated areas due to limited land for disposal of large tonnages of waste. The idea of using poultry litter to treat crop residues originated from alkali treatment aimed at breaking the lignin bond in such residues and straws thus releasing the energy contained in them for use by the animal fed such material. Poultry litter has high uric acid which under high pressure is hydrolyzed to ammonia thereby acting on thelignin bond (Sundstol and Worth, 1984).

Micro organisms in the rumen have a unique ability of utilizing uric acid and other forms of Non Protein Nitrogen (NPN) contained in animal waste to make their body protein which is subsequently digested in the lower gut for use by the host animal.

Drying and or ensiling poultry waste either alone or with green or dried roughage has been the most feasible and effective way of destroying pathogens (Chaudhry et al., 1993). Pennisetum pedicellatum, commonly known as deenath grass world wide and Kyasuwa (Nigeria) is an annual grass growing up to $40-150 \mathrm{~cm}$ high (Bogdan, 1977). It is one grass that is not readily accepted by animals when in the hay form, it was hypothesized that the feeding value might be improved by ensiling with poultry litter.

Corresponding Author: M. Baba, Department of Animal Science, Bayero University, Kano, Nigeria 
Objectives: The objective of the study were:

- To determine the nutritive value of kyasuwa hay ensiled with poultry litter in varying proportions

- To determine the proportion that will improve the nutritive value the most

\section{MATERIALS AND METHODS}

Experimental site: The experiment was conducted in the Animal Science laboratory of the Faculty of Agriculture, Bayero University Kano Nigeria. Kano lies between latitude $9^{\circ} 30^{\prime}$ and $12^{\circ} 30^{\prime}$ North and longitude $9^{\circ} 30^{\prime}$ and $8^{\circ} 42^{\prime}$ East in the Northern Guinea savannah zone. The zone is characterized by wet season (May-September) and dry season (October-April). Annual mean rainfall ranges from $600-1000 \mathrm{~mm}$.

Preparation and ensiling of material: Kyasuwa hay was collected within the vicinity of Bayero University Kano during the dry season of 2008. The hay was chopped manually into smaller pieces $(1-2 \mathrm{~cm}$ length) and mixed with poultry litter previously dried in the sun in varying ratios; 80:20, 70:30, 60:40 and 50:50 (by weight), respectively each ratio represented a treatment and was replicated three times in a completely randomized design, there was also a control; 100:0 (without poultry litter). All mixtures were put in polythene bags with each replicate contained in a bag, little quantity of water $(50 \mathrm{~mL})$ was sprinkled on to each replicate mixture and then agitated. The polythene bags were tightly sealed and tied with a string after wards to ensure airtight anaerobic condition. The bags were put inside plastic buckets which were tightly covered with lids.

Following incubation period of 21 days, a pair of forceps was used to scoop the resultant silage from the bags; the silage was assessed for aroma and $\mathrm{pH}$ by three independent scorers on a scale of 1-4 as shown in Table 1.

Chemical analysis: $\mathrm{pH}$ of silage was determined by putting $50 \mathrm{~g}$ sample in water using digital $\mathrm{pH}$ meter. Dry matter was determined by drying the silage at $65^{\circ} \mathrm{C}$ for $48 \mathrm{~h}$. Crude Protein (CP) was measured using Kjeldahl method $(\mathrm{N} \times 6.25)$ while other proximate constituents, Ether Extract (EE), ash, Crude Fiber (CF) and Nitrogen Free Extract (NFE) according to procedures described by $\mathrm{AOAC}(1980)$.

Table 1: Scale of 1-4 for silage assessment

\begin{tabular}{ll}
\hline Scale & Aroma score \\
\hline 1 & Putrid/Rancid \\
2 & Pleasant \\
3 & Sweet \\
4 & Very sweet \\
\hline
\end{tabular}

Statistical analysis: All data were analyzed using the General Linear Model (GLM) procedures of the SAS (1987). Data were subjected to analysis of variance.

\section{RESULTS AND DISCUSSION}

The $\mathrm{pH}$ and aroma properties of the silage are shown in Table 2. Significant differences $(\mathrm{p}<0.05)$ were observed among the treatments with regard to $\mathrm{pH}$. Ensiling kyasuwa with poultry litter increased the $\mathrm{pH}$ of the resultant silage albeit no definite pattern was observed. The highest $\mathrm{pH}$ was recorded in treatment 50:50 (7.21) with the least in control (5.51).

This agrees with the findings of Rasool et al. (1998) who reported an increase in initial and subsequent $\mathrm{pH}$ of sudax grass ensiled with $30 \%$ Broiler litter and $6 \%$ molasses however, the $\mathrm{pH}$ values obtained were lower than the ones recorded in this study. Hadjipanayiotou (1994) observed a similar trend with tomato pulp and poultry litter silage.

The increase in silage $\mathrm{pH}$ observed might be due to buffering capacity as a result of ash and ammonia from uric acid hydrolysis (Leterme et al., 1992). The $\mathrm{pH}$ levels were above the desired level for a good quality silage (5.0) and may indicate the lack of organic acids being generated by fermentation. Graph of $\mathrm{pH}$ of the silages is shown in Fig. 1.

Aroma of the silage ranged from sweet to putrid/rancid, treatments $80: 20$ and control(100:0) had sweet aroma while 50:50 was repugnant (putrid/rancid). The low aroma score of treatment 50:50 may be

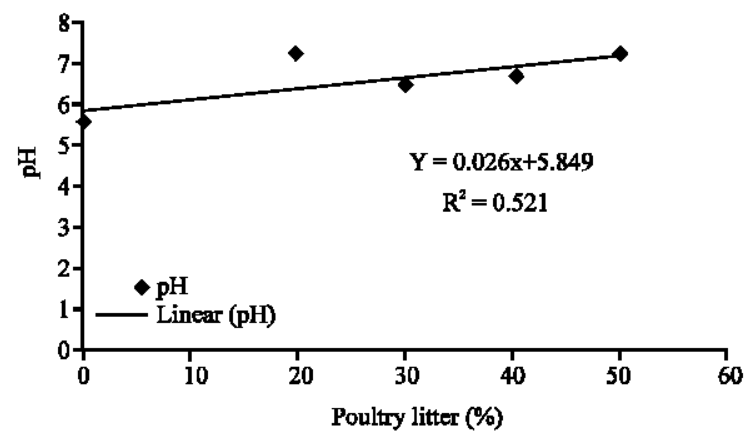

Fig. 1: Linear regression graph of $\mathrm{pH}$

Table 2: The $\mathrm{pH}$ and aroma properties of silage

\begin{tabular}{lcc}
\hline Treatments & $\mathrm{pH}$ & Aroma \\
\hline $100: 0$ & $5.51^{\mathrm{c}}$ & $3.00^{\mathrm{b}}$ \\
$80: 20$ & $7.19^{\mathrm{a}}$ & $3.00^{\mathrm{b}}$ \\
$70: 30$ & $6.41^{\mathrm{b}}$ & $2.00^{\mathrm{c}}$ \\
$60: 40$ & $6.59^{\mathrm{b}}$ & $2.00^{\mathrm{c}}$ \\
$50: 50$ & $7.21^{\mathrm{a}}$ & $1.41^{\mathrm{c}}$ \\
LSD & 0.44 & 0.79 \\
\hline Means within columns with different superscripts are statistically significant \\
(p<0.05)
\end{tabular}


Res. J. Anim. Sci., 4 (5): 117-120, 2010

Table 3: Proximate composition of silage

\begin{tabular}{llllrcc} 
Treatments & DM (\%) & CP (\%) & CF (\%) & EE (\%) & ASH (\%) & NFE (\%) \\
\hline $100: 0$ & 92.29 & $1.64^{\mathrm{c}}$ & $36.37^{\mathrm{a}}$ & $10.64^{\mathrm{ab}}$ & $13.11^{\mathrm{ab}}$ & $13.69^{\mathrm{c}}$ \\
$80: 20$ & 92.77 & $3.01^{\mathrm{bc}}$ & $20.46^{\mathrm{b}}$ & $9.80^{\mathrm{b}}$ & $3.68^{\mathrm{c}}$ & $63.06^{\mathrm{a}}$ \\
$70: 30$ & 92.87 & $3.28^{\mathrm{ab}}$ & $19.38^{\mathrm{b}}$ & $10.19^{\mathrm{ab}}$ & $17.90^{\mathrm{a}}$ & $49.26^{\mathrm{bc}}$ \\
$60: 40$ & 92.92 & $3.56^{\mathrm{ab}}$ & $20.08^{\mathrm{b}}$ & $8.30^{\mathrm{b}}$ & $4.67^{\mathrm{bc}}$ & $63.34^{\mathrm{a}}$ \\
$50: 50$ & 93.18 & $4.65^{\mathrm{a}}$ & $15.95^{\mathrm{b}}$ & $11.70^{\mathrm{b}}$ & $5.07^{\mathrm{bc}}$ & $62.64^{\mathrm{ab}}$ \\
LSD & NS & 1.55 & 9.01 & 3.13 & 9.02 & 9.02 \\
\hline
\end{tabular}

Means within the same column with different superscript are statistically significant $(\mathrm{p}<0.05)$

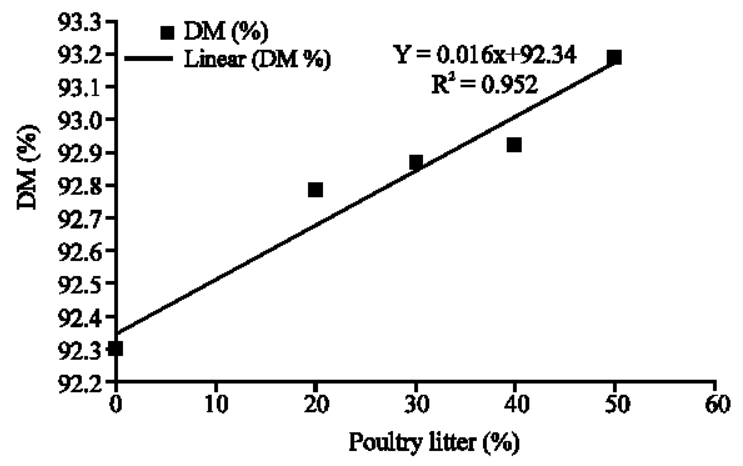

Fig. 2: Linear regression graph for DM

attributed to the presence of mould growth observed in one of the replicate. The proximate composition of silage is shown in Table 3.

Ensiling with poultry litter increased the Dry Matter (DM) composition of silage, no significant difference was observed among the treatments, DM increased linearly from $92.77 \%$ in treatment $80: 20-93.18 \%$ in $50: 50$. This is supported by the report of Al-Rokayan et al. (1988) when Broiler litter was ensiled with sorghum forage in the proportions 0:100, 25:75, 35:65 and 45:55. Similar result was reported by Flachowsky and Hennig (1990). Graph of dry matter composition of the silages is shown in Fig. 2.

Crude protein composition of the silage was also found to have increased with increased proportion of poultry litter. Crude protein increased steadily from $3.01 \%$ in treatment $80: 20-4.65 \%$ in 50:50. Treatment 50:50 was superior $(p<0.05)$ to treatment $80: 20$ and the control and had the highest crude protein content in absolute terms when compared to other treatments (70:30 and 60:40). Ngele et al. (2006) treated rice straw with poultry litter at different ratios and recorded highest crude protein in ratio 50:50. The crude protein of sorghum forages ensiled with broiler litter increased with increased proportion of poultry litter (Al-Rokayan et al., 1988; Flachowsky and Hennig, 1990). Graph of the crude protein content of the silages is shown in Fig. 3.

In contrast to the foregoing trend, crude fiber declined with increased proportion of poultry litter from $20.46 \%$ in treatment 80:20-15.95\% in 50:50. Rasool et al. (1998) observed a decline in NDF, hemicelluloses and cellulose (fiber component) in sudax fodder ensiled with broiler litter and molasses. Magar and Fontenot (1988) and

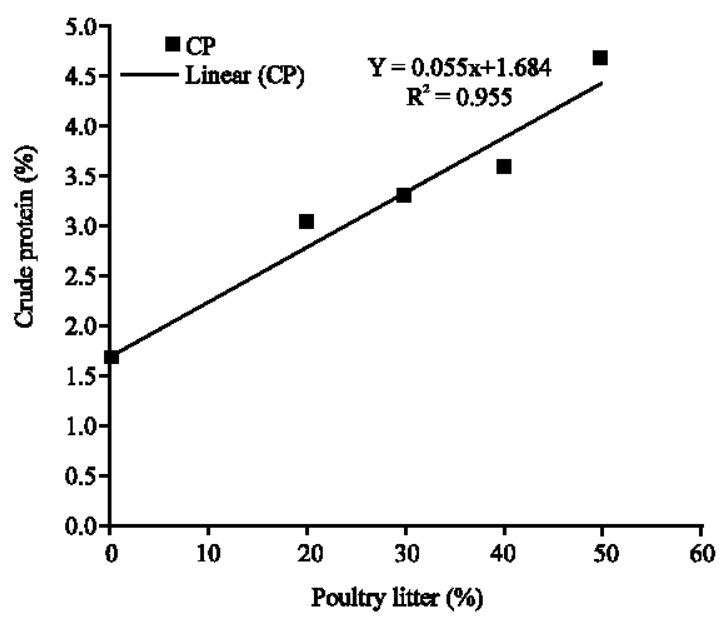

Fig. 3: Linear regression graph for CP

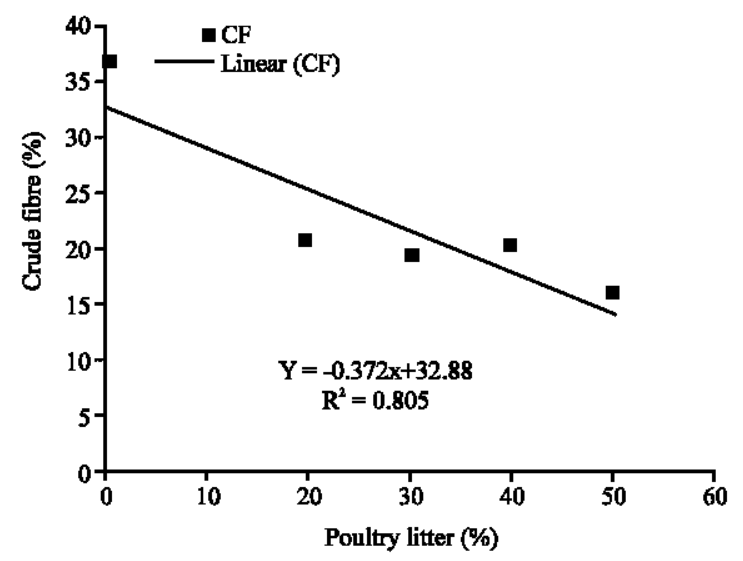

Fig. 4: Linear regression graph for $\mathrm{CF}$

Rasool et al. (1996) also observed a similar trend. The decline in crude fiber might be due to hydrolysis of uric acid in poultry litter to ammonia which can effectively break down the lignin bond in rice straw (Ngele et al., 2006). Graph of the crude fiber composition of the silages is shown in Fig. 4.

Ether extact components of the treatments were not significantly different $(\mathrm{p}>0.05)$ ensiling with poultry litter lowered the EE composition of silage save for treatment $50: 50$ observed to be higher $(\mathrm{p}>0.05)$ than control. The result of this study differs from that of Mthiyane et al. (2001) who observed increase in EE composition of sugarcane top ensiled with broiler litter and that of Ngele et al. (2006).

Ensiling with poultry litter decreased the ash content of silage. The ash contents of all treatments were virtually lower than the control except for treatment $70: 30(17.90 \%)$ found to be astonishingly higher $(\mathrm{p}<0.05)$ than all treatments and statistically at par $(p>0.05)$ with the control. Among the treatments, the ash content was observed to increase with increased proportion of poultry 
litter from $3.68 \%$ in treatment $80: 20-5.07 \%$ in $50: 50$. The cause of the astronomical rise in the ash content of treatment $70: 30(17.90 \%)$ could not be easily fathomed. This contrast with the findings of Al-Rokayan et al. (1988) and Flachowsky and Hennig (1990) who observed a linear increase in ash with increased proportion of broiler litter. All treatments had higher $(\mathrm{p}<0.05)$ nitrogen free extract than the control, suggestive of the fact that addition of poultry litter had increased the NFE content of silage however, no definite pattern was observed. Among the treatments, 80:20, 60:40 and 50:50 were superior $(p<0.05)$ to 70:30. This deviates from the result of Cruz and Viado (1981) who recorded a decrease in NFE of para grass silage treated with poultry litter.

\section{CONCLUSION}

Ensiling kyasuwa hay with $50 \%$ poultry litter significantly increased the CP content from 1.64-4.65\% and caused a decline in $\mathrm{CF}$ content by about $43 \%$. The significant improvement in $\mathrm{CP}$ and the corresponding reduction in $\mathrm{CF}$ are indicative of improvement in feeding value of the ensiled hay which may ultimately improve intake by animals. It can therefore be concluded that ensiling kyasuwa with poultry litter up to $50 \%$ significantly improved the feeding value of the hay.

However, as a recommendation an extra protein supplement might be needed in order to meet the protein requirements of animals during dry season.

\section{REFERENCES}

AOAC, 1980. Official Methods of Analysis. 13th Edn., Association Official Analytical Chemistry, Washington, DC.

Al-Rokayan, S.A., Z. Naseer and S.M. Chaudhry, 1988. Nutritional quality and digestibility of sorghumbroiler litter silages. Anim. Feed Sci. Tech., 75: 65-73.

Bhattacharya, A.N. and J.C. Taylor, 1975. Recycling of animal waste as a feedstuff: A review. J. Anim. Sci., 41: 1438-1457.

Bogdan, A.V., 1977. Tropical Pasture and Fodder Plants. Longman, London.

Chaudhry, S.M., Z. Naseer and D.M. Chaudhry, 1993. Fermentation characteristics and nutritive value of broiler litter ensiled with corn forage. Food Chem., 48: $51-55$.

Cruz, Z.G. and F.M. Viado, 1981. Unconventional feed stuffs in animal production: Proximate analysis of fermented grass with or without molasses, poultry manure and or Monosodium glutamate fermented mother liquor. Philipp. J. Vet. Med., 20: 122-132.
$\mathrm{FAO}, 1983$. Integration of crops and livestock in West Africa. FAO Animal Production and Health Paper 41, Rome.

Flachowsky, G. and A. Hennig, 1990. Composition and digestibility of untreated and chemically treated animal excreta for ruminants-A review. Biol. Waste, 31: $17-36$.

Fontenot, J.P. and V. Jurusbescu, 1980. Processing of Animal Waste by Feeding to Ruminants. In: Digestive Physiology and Metabolism in Ruminants, Ruckebush, Y. and P. Thivead (Eds.). AVI Publishing Co., USA., pp: 641-662.

Hadjipanayiotou, M., 1994. Voluntary intake and performance of ruminant animals offered poultry litter-olive cake silage. Livest. Res. Rural Dev., Vol. 6, No. 2.

Humphreys, L.R., 1991. Tropical Pasture Utilization. Cambridge University Press, Cambridge, pp: 206.

Leterme, P., A. Thewis and M. Culot, 1992. Supplementation of pressed sugar-beet pulp silage with molasses and urea, laying hen excreta or soybean meal in ruminant nutrition. Anim. Feed Sci. Tech., 39: 209-225.

Magar, S.M. and J.P. Fontenot, 1988. Nutritional value of ensiled deep pit caged layer waste-corn forage mixtures. Virginia Technical Livestock Reserch Report No 7, Blacksburg, pp: 133-136.

Mthiyane, D.M.N., I.V Nsahlai and M.L.K. Bonsi, 2001. The nutritional composition, fermentation characteristics, in sacco degradation and fungal pathogen dynamics of sugarcane tops ensiled with broiler litter with or without water. Anim. Feed Sci. Tech., 94: 171-185.

Ngele, M.A., T.A. Adegbola and S.E.S. Bogoro, 2006. Nutritive value of rice straw treated with poultry litter. Proceedings of the 31st Annual Conference of Nigerian Society for Animal Production, March 12-15, Bayero University, Kano, pp: 18-21.

Rasool, S., M.A. Sial, Ahsan-ul-Haq and A. Jamil, 1998. Chemical changes during ensiling of sudax fodder with broiler litter. Anim Feed Sci. Tech., 72: 347-354.

Rasool, S., S.H. Hanjra and A. Jamil, 1996. Effect of ensiling sudax fodder with broiler litter and Candida yeast on the changes in different fiber fractions. Anim. Feed Sci. Tech., 57: 325-333.

SAS, 1987. Procedures Guide for Personal Computers. Version 6, SAS Institute Inc., Cary NC. USA., pp: 373.

Sundstol, F. and E.M.C Worth, 1984. Ammonia Treatment. In: Straw and other Fibrous Byproducts as Feed, Sundstol, F. and E.M. Owens (Eds.). Elsevier, Amsterdam, pp: 196249. 